\title{
DĚJINY STŘEDOVĚKÉ A RANĚNOVOVĚKÉ VZDĚLANOSTI V ČESKÉM HISTORICKÉM VÝZKUMU. TRADICE - AKTUÁLNÍ TRENDY - PERSPEKTIVY
}

\author{
MLADA HOLÁ - MARTIN HOLÝ
}

\author{
HISTORY OF MEDIEVAL AND EARLY MODERN EDUCATION IN CZECH HISTORICAL \\ RESEARCH: TRADITION - CURRENT TRENDS - PERSPECTIVES
}

The aim of this contribution is to bring a systematic overview of the development of Czech historical research pertaining to the history of education in pre-modern era, especially in the fourteenth to eighteenth century. Within a broader European context, the authors investigate both local research traditions and current trends influenced by the subjects of research and new methods in international historiography or related social sciences and humanities. From the perspective of analysing directions of research in the history of pre-modern education, the article charts several approaches adopted especially in scientific production of the past two decades. In its concluding part, this contribution formulates some potential subjects of further research and outlines methodological approaches suitable for dealing with them.

Keywords: history of education - pre-modern period - research trends - historiographic overview

DOI: $10.14712 / 23365730.2019 .3$

Vzdělanostní dějiny, respektive tradičněji dějiny vzdělanosti, představují disciplínu, která se jako podobor historické vědy konstituovala na konci 19. století. Tehdy stejně jako v prvních třech desetiletích 20. století vydala také první výrazné plody. Vyšla řada monografií vztahujících se zejména $\mathrm{k}$ dějinám univerzit a některých preuniverzitních vzdělávacích institucí a byly učiněny rovněž některé pokusy o syntetické zpracování dějin vzdělanosti a pedagogiky v předmoderní době. Z hlediska středoevropské perspektivy ovšem i v celoevropském kontextu jsou pravděpodobně nejzásadnější syntézy vzniklé v německojazyčném prostředí, vedle nich pak ovšem také některé práce frankofonní či anglojazyčné. ${ }^{1}$

1 Na jednotlivé tituly zde pro jejich množství není možné odkazovat. Ze syntetických prací k předmoderní době srov. alespoň Friedrich PAulsen, Geschichte des gelehrten Unterrichts auf den deutschen Schulen und Universitäten vom Ausgang des Mittelalters bis zur Gegenwart mit besonderer Rücksicht auf den klassischen Unterricht, Leipzig 1885; Georg MerTz, Das Schulwesen der deutschen Reformation im 16. Jahrhundert, Heidelberg 1902; François GuYE, Histoire de l'instruction et de l'éducation, Lausanne - Paris 1906; Ellwood P. Cubberley, The History of Education, Boston - New York 1920; William Boyd, The History of Education, London 1921. Viz také úvody a soupisy literatury některých moderních syntéz: Hilde de RiDDER-SYMOENs (ed.), A History of the University in Europe, I-II, Cambridge 1992-1996; Notker HAMmERsteIn (Hg.), Handbuch der deutschen Bildungsgeschichte, I, 15. bis 17. Jahrhundert. Von der Renaissance und der Reformation bis zum Ende der Glaubenskämpfe, München 1996; Rudolf Tippelt (Hg.), Handbuch Bildungsforschung, Opladen 2002; 
Další výrazný rozvoj tohoto oboru nastal po druhé světové válce. Čím dál větší měrou se v něm začaly projevovat nejen podněty intelektuálních, kulturních či sociálních dějin, ale také ostatních humanitních a sociálních věd, pedagogiky, sociologie či lingvistiky. Vznikla řada nových specializovaných pracovišt', byla založena některá nová periodika, uspořádána série sympozií. Vývoj v posledních desetiletích zřetelně ukazuje, že dějiny vzdělanosti již nelze vnímat úzce prizmatem historiografie, nýbrž jako disciplínu integrující v sobě celou r̆adu dalších oborů.

V českém prostředí lze do jisté míry zaznamenat podobný vývoj jako v zahraničí. Za zakladatelské práce je možné považovat na jedné straně četné monografie Zikmunda Wintra, na straně druhé první pokusy o větší syntézu z pera Otakara Kádnera. Od 50. let 20. století byl výzkum dějin vzdělanosti soustředěn zejména v nově založeném Ústavu dějin Univerzity Karlovy. Některé cenné práce vznikly však také na jiných pracovištích. Podrobněji se k vývoji mezi druhou světovou válkou a 90. lety věnovat nebudeme, nebot' se na něj na Sjezdu historiků v Hradci Králové soustředil Michal Svatoš. ${ }^{2}$

Od té doby uplynulo však takřka již dvacet let. A právě na ně se soustředí tento př́spěvek. Ve vztahu k období středověku a raného novověku se pokusí poukázat nejen na klíčová témata a badatelské trendy oněch posledních dvou decennií ovlivněné do jisté míry zkoumanou problematikou i metodami zahraniční historiografie, př́padně příbuzných sociálních a humanitních věd, ale také na výraznou sílu domácí tradice, která dosud podstatně ovlivňuje podobu výzkumu dějin vzdělanosti. V poslední části se pak pokusíme formulovat některá potenciální témata dalšího bádání.

Dosud nejvýraznějším proudem dějin středověké a raně novověké vzdělanosti u nás jsou samotné dějiny školství. V centru pozornosti domácího bádání o školském systému středověku až 18. století nestály přitom pouze univerzity, které ve většině evropských zemí výzkumu dějin školství dominují, nýbrž také preuniverzitní vzdělávací instituce, a to jak „veřejné“, tak také některé privátní. Naopak elementární školství až na některé výjimky, o nichž se zmíníme ještě později, zůstává stále do značné míry stranou výzkumu v České republice.

Začneme-li univerzitními dějinami v českém historickém výzkumu po roce 2000, ty bezprostředně navázaly na výsledky staršího bádání. V domácích i zahraničních časopisech a sbornících vyšla celá řada studií $\mathrm{k}$ dějinám pražských vysokých škol a v menší míře také olomoucké akademie, větších knižních monografií bylo ovšem vydáno nemnoho. Všechny se přitom vztahují k pražskému vysokému učení. Kromě výborů Šmahelových starších studií vydaných v letech 2007 a 2016, Petráňovy knihy o Karolinu a drobné publikace k osobnostem pražské univerzity od 15. do 17. století, jež vznikla pod vedením Petra Hlaváčka, jde zejména o Stočesovu disertaci o pražských univerzitních národech a Nodlovu práci o Kutnohorském dekretu, obě vydané v roce 2010, a dále o habilitaci Mlady Holé ke studentským kolejím pražské univerzity ve 14.-17. století a český překlad monografie

Wolfgang NeugeBauer, Bildungsgeschichte, I-III, Geschichte in Wissenschaft und Unterricht 56, 2005, Heft 10, s. $584-593 ; 11$, s. 644-656; 12, s. 719-731.

2 Zikmund WinTER, Děje vysokých škol pražských od secessí cizich národů po dobu bitvy bělohorské (1409-1622), Praha 1897; TÝž, O životě na vysokých školách pražských knihy dvoje. Kulturni obraz XV.-XVI. století, Praha 1899; TY̌ž, Život a učení na partikulárnich školách v Čechách v XV. a XVI. století, Praha 1901; Otakar Kádner, Dějiny pedagogiky, I-II, Praha 1923; Michal Svatoš, Misto ,, dějin vzdělanosti “v poválečné české historiografii, in: Práce z Archivu Akademie věd, řada A, sv. 7, 2002, s. 13-20 (tamtéž vyšla na s. 23-35 také cenná studie Blanky ZiLYNSKÉ, Prameny a pomůcky ke studiu dějin vzdělanosti. Bilance a desiderata). 
francouzského badatele Oliviera Marina o genezi pražského reformního hnutí s velkým podílem univerzitních reálií a osob z akademického prostředí. ${ }^{3}$

K domácímu výzkumu univerzitních dějin je pak možné rovněž započítat bohužel nevydanou disertaci Jany Wojtucké pojednávající o nezdařeném pokusu založit univerzitu ve slezské metropoli Vratislavi na počátku 16. století. Na rozdíl od období do roku 2000 vyšlo jen minimum pramenných edic $\mathrm{k}$ dějinám univerzit. V knižní podobě vlastně pouze Šmahelovy a Silágiové Catalogi librorum vetustissimi Universitatis Pragensis. Některé edice cenných univerzitních pramenů jsou pak také aktuálně v tisku či v př́pravě. ${ }^{4}$

Z témat spojených s dějinami univerzit a pojednaných bud' v dílčích studiích, anebo monografiích primárně jinak zaměřených byla opět v návaznosti na starší bádání zkoumána akademická předmoderní peregrinace, vztahy mezi pražskou univerzitou a dalšími akademickými institucemi v Evropě, fenomén vzdělanostního mecenátu, kariéry někdejších studentů či profesorů pražské univerzity, jejich literární činnost apod. Pokud jde o metody využité v uvedených pracích, $\mathrm{k}$ těm se dostaneme později. ${ }^{5}$

V posledních letech nastal významný posun ve výzkumu preuniverzitních vzdělávacích institucí. Zejména se to týká bádání o církevním školství, a to nejen v pobělohorské době. Kromě dílčích př́ispěvků zde vznikly i některé inovativní práce vycházející většinou z disertací. Týká se to zejména knihy Každodenní život učitele a žáka Kateřiny

3 Josef Petráň, Karolinum, Praha 2010; František Šmahel, Die Prager Universität im Mittelalter - The Charles University in the Middle Ages. Gesammelte Aufsätze - Selected Studies, Leiden - Boston 2007; Martin NodL, Dekret kutnohorský, Praha 2010, německé vydání: Kuttenberger Dekret von 1409. Von der Eintracht zum Konflikt der Prager Universitätsnationen (Forschungen zur Geschichte und Kultur des östlichen Mitteleuropa 51), Wien - Köln - Weimar 2017; Jiří StočEs, Pražské univerzitní národy do roku 1409, Praha 2010; Petr HLAVÁČEK a kol., Kacírská univerzita. Osobnosti pražské utrakvistické univerzity 1417-1622, Praha 2013; František ŠMAHEL, Alma mater Pragensis. Studie k počátkům Univerzity Karlovy, Praha 2016; Mlada Holá, Studentské koleje pražské univerzity v pozdním středověku a raném novověku: dějiny - správa - úřední písemnosti (do roku 1622), Praha 2017; Olivier MARIN, Geneze pražského reformniho hnutí 1360-1419, Praha 2017 (originál vyšel v r. 2005).

4 Jana Wojtucka, Nesplněný sen. Předpoklady, průběh a přičiny neúspěšného zřizení univerzity ve Vratislavi roku 1505. Př́spěvek $k$ dějinám vzdělanosti ve vedlejšich zemích Koruny české, disertace FF UK, Praha 2006 (publikována pouze dílčím způsobem v několika studiích); František ŠMAHEL - Zuzana SiLAGIOvÁ (ed.), Catalogi librorum vetustissimi Universitatis Pragensis: Die ältesten Bücherkataloge der Prager Universität, Turnhout 2015; Mlada Holá - Martin Holý (Hg.), Das Studentenkolleg der Böhmischen Nation der Prager Universität. Edition der Rechnungen aus den Jahren 1541-1611, Berlin 2019. Přehled nejvýznamnějších titulů přináši periodikum History of Universities.

5 Pouze výběrově srov. alespoň Milena Lenderová, Studenti ze střední Evropy na lékařské fakultě univerzity v Montpellieru (1600-1789), Historický obzor 10/7-8, 1999, s. 173-178; Michal Svatoš, Češti studenti v Sieně, in: Alena Pazderová - Lucia Bonelli Conenna (edd.), Siena v Praze. Dějiny, umění, společnost, Praha 2000, s. 59-63; Miroslav KunŠTÁt, Od Vltavy k Neckaru. Akademická peregrinace mezi pražskou a heidelberskou univerzitou v průběhu šesti staletí, in: O dějinách a politice. Janu Křenovi k sedmdesátinám, Ústí nad Labem 2001 s. 71-97; Milena Lenderová, U Herkula! Tolik výhod pro cizince! Studenti z českých zemí na univerzitě ve francouzském Orléansu, Dějiny a současnost 2006, č. 5, s. 15-19; Jiří PEšEK, Studijní cesty mládeže z českých zemí v době predbělohorské. Úvaha nad sociokulturními kontexty vzdělanostních migrací, in: Jiří Mikulec - Miloslav Polívka (edd.), Per Saecula ad tempora nostra. Sborník prací k šedesátým narozeninám prof. Jaroslava Pánka, Praha 2007, s. 448-452; Ivan HLAVÁČEK, Zum universitären Mäzenatentum des Spätmittelalters und der Frühen Neuzeit (Am Beispiel der Prager Universität), AUC-HUCP 49/2, 2009, s. 169-184; Michal Svatoš, Poslední absolventi pražské utrakvistické akademie (1618-1620), AUC-HUCP, 50/1, 2010, s. 233-241; Jiří STоČEs, Kariéry př́slušniků saského národa pražské právnické univerzity imatrikulovaných $v$ letech 1386-1417, AUC-HUCP, 52/2, 2012, s. 17-28; Martin Holý, Vzdělanostní migrace v česko-německém prostoru $v$ 16. a raném 17. století, in: Navzdory hranici: migrační procesy na česko-německém pomezí: př́spěvky z odborné konference, Cheb 27.-29. května 2013, Plzeň 2013, s. 18-31; TÝž, Vzdělanostní mecenát v zemích České koruny (1500-1700), Praha 2016. 
Bobkové-Valentové či práce Hedviky Kuchařové o premonstrátském Norbertinu. Některé cenné práce vyšly však také $\mathrm{k}$ dominikánům, františkánům a piaristům. Vedle nich nelze však nezmínit také některé nové pohledy na protestantské školství v zemích České koruny v předbělohorském období. ${ }^{6}$

Za cenné lze pak považovat rovněž pokusy o dějiny školství v určitém regionu, např́iklad v jižních Čechách (práce Miroslava Novotného). Výrazně pak naše znalosti o předmoderním preuniverzitním školství obohatily také některé monografie vztahující se $\mathrm{k}$ dějinám jednotlivých lokalit s výraznou vzdělanostní tradicí (jako vzorové lze uvést např́ílad př́slušné pasáže z dějin Velkého Meziř̌́čí z pera Martina Štindla), případně některé syntetické pohledy na školství v konkrétní lokalitě vztahující se rovněž $\mathrm{k}$ předmoderní době, např́klad Dějiny žateckého gymnázia vydané kolektivem pod vedením Jiř́ího Matyáše. ${ }^{7}$

Zcela zásadní jsou pak také některé edice dochovaných pramenů, např́klad jezuitských konsvetudinářů vydávaných Kateřinou Bobkovou-Valentovou, která je rovněž spoluautorkou edice latinských školních her vztahujících se $\mathrm{k}$ Janu Nepomuckému publikované v rámci řady Theatrum neolatinum, v níž zpř́stupnila Magdaléna Jacková také hry určené pro gramatikální třídy Tovaryšstva Ježíšova. Školní divadlo, zejména pak právě divadlo jezuitské, se dočkalo také některých syntetických prací, at již se to týká knihy Petra Polehly z roku 2011, anebo Magdalény Jackové ze stejného roku. ${ }^{8}$

Některé dílčí práce byly vydány rovněž k divadelním představením dalších katolických církevních řádů, stejně jako i k nekatolickému školnímu divadlu. V centru pozornosti bádání po roce 2000 se pak ocitly rovněž některé dalšš fenomény úzce spjaté s prostředím

6 Václav BARTŮŠEK, Šiřeni piaristických kolejí a škol v Čechách, na Moravě a ve Slezsku v 17. a 18. století, in: Paginae historiae 11, 2003, s. 32-68; Martin Cholasta, Latinské školy v Hradci Králové, in: Příspěvky k dějinám královéhradeckého středního školství. Sborník referátů z konference konané u př́ležitosti 10. výročí založení Biskupského gymnázia B. Balbína v Hradci Králové dne 6. června 2002 v Hradci Králové, Hradec Králové 2003, s. 4-35; Jana UhlírovÁ, Bratrské školství v Čechách a na Moravě, Studia Comeniana et Historica 34/71-72, 2004, s. 54-61; Kateřina BoBKovÁ-VALENTOVÁ, Každodenní život učitele a žáka jezuitského gymnázia, Praha 2006; Tomáš ČERnUšÁK, Proměny rádového školství dominikánů v českých zemích (nástin vývoje ve 14.-18. stoleti), in: Sborník prací Pedagogické fakulty Masarykovy univerzity, Řada společenských věd 21, 2006, s. 3-10; Hedvika KuchaŘová, Premonstrátská kolej Norbertinum v Praze. Alternativy univerzitního vzdělání v 17. a 18. století, Praha 2011; Kateřina BobkovÁ-Valentová - Martin Holý - Martina Ondo GReČENKOvÁ, Církve, vzdělávání a věda, in: Jiří Mikulec et al., Církev a společnost raného novověku v Čechách a na Moravě, Praha 2012, s. 211-268; Martin HoLÝ, Vereitelte Hoffnungen? Der rudolfinische Majestätsbrief und das nichtkatholische höhere Schulwesen in Böhmen, in: Religion und Politik im frühneuzeitlichen Böhmen. Der Majestätsbrief Kaiser Rudolfs II. von 1609, Stuttgart 2014, s. 171-180; Markéta RŮČKovÁ - Jiří. A. ČEPELÁK (edd.), Studium a korespondence kněžského dorostu Jednoty bratrské v letech 1610-1618: „poslušenství synovské vzkazuji Vám, můj nejmilejši pane otče “, Praha 2014. Cenné jsou rovněž některé nové př́spěvky k dějinám městského partikulárního školství. Srov. alespoň Zdeněk VyBíraL, Viri litterati a město Tábor na počátku novověku (1550-1620), Husitský Tábor 13, 2002, s. 455-491; Bořek NEŠKUDLA, Učitelé školy u sv. Jindřicha na Novém Městě pražském v predbělohorském období, AUC-HUCP 47/1-2, 2007, s. 99-116.

7 Miroslav NovotnÝ a kol., Dějiny vyššiho školství a vzdělanosti na jihu Čech od středověkých počátkủ do současnosti, České Budějovice 2006; Dalibor HodEČEK a kol., Velké Meziřičí v zrcadle dějin, Brno 2008, s. 129nn. (autorem pasáží o velkomeziříčském gymnáziu je Martin Štindl); Jiří MATYÁš, Dějiny žateckého gymnázia: Schola Zatecensis, Žatec 2009.

8 Magdaléna Jacková, Divadlo jako škola ctnosti a zbožnosti: jezuitské školské drama v Praze v první polovině 18. století, Praha 2011; Petr Polehla, Jezuitské divadlo ve službě zbožnosti a vzdělanosti, Červený Kostelec 2011; Kateřina Bobková-Valentová (ed.), Consuetudines Assistentiae Germaniae, I, Praha 2011 (II. díl je v tisku); Kateřina BobkovÁ-ValentovÁ - Alena BočKovÁ - Magdaléna JAckovÁ - Martin BažIL - Eva PAUEROVÁ - Jan ZDICHYNEC - Zdeněk ŽALud (edd.), Sv. Jan Nepomucký na jezuitských školních scénách (= Theatrum neolatinum I), Praha 2015; Magdaléna JACKOvÁ (ed.), Nejmirnějši Pallas: hry určené gramatikálním tř́dám jezuitských gymnázii (= Theatrum neolatinum II), Praha 2016. 
předmoderních preuniverzitních škol, jako byly vyučované předměty, texty užívané ve výuce, její metody, jazyky výuky, dále financování studií žáků, jejich migrace za vzděláním, postavení učitelů, jejich vzdělávání, kariéry, literární činnost apod. Za nejcennější považujeme skutečnost, že se v uplynulých letech podařilo výrazně překročit rok 1620. Některé práce se přitom zaměřují na období dlouhého trvání a mohou tak sledovat klíčové dlouhodobé vývojové trendy. ${ }^{9}$

Pokud jde o elementární školství, k němu bylo vydáno nejméně prací. Není to dáno ani tak nezájmem o ně v českém výzkumu, ale spíše tím, že se institucionalizovalo v předmoderní době jen velmi pozvolna a také pramenů je pro ně $\mathrm{k}$ dispozici oproti vyšším stupňům vzdělávání podstatně méně. Přesto byly vydány některé dílčí cenné studie $\mathrm{k}$ elementárnímu školství, zejména pak pro 17. a 18. století, většinou pak opět ve vztahu k církevnímu školství. Některé práce pro období osvícenství sledovaly i mimocírkevní vzdělávací systém, stejně jako i další badatelské otázky. Část z nich se rovněž soustředila na školské reformy osvícenského absolutismu. ${ }^{10}$

Z hlediska předškolní pedagogiky předmoderní doby lze kromě nové edice Komenského Informatoria školy mateřské zaznamenat $\mathrm{z}$ této oblasti pouze některé dílčí prríspěvky. Podstatně výraznější zájem domácích badatelů se v uplynulých letech naopak soustředil na různé otázky spojené se vzděláváním některých specifických skupin obyvatelstva českých zemí. Zejména se to týká výzkumu dějin edukace nobility. K ní bylo vydáno několik monografí́. Ty se přitom vztahovaly nejen $\mathrm{k}$ předbělohorskému období, ale také k pokročilému 17. a 18. století. V některých př́ipadech přitom nesledovaly pouze samotné vzdělávání elit, ale také jeho dopady, to znamená např́iklad vliv na učenecké kontakty udržované

9 Srov. alespoň výběrově: Eva DoležAlovÁ, Seminář sv. Václava a konvikt sv. Bartoloměje na Starém Městě pražském, Pražský sborník historický 31, 2000, s. 186-261; K. BoBkovÁ-VALENTovÁ, Každodenní život učitele a žáka; Václav BARTƯšEK, Počátky piaristického školního divadla v Benešově před třemi stoletími, in: Sborník vlastivědných prací z Podblanicka 44-47, 2007, s. 237-248; Petr PoleHLA - Zdeněk HoJdA (edd.), Náboženské divadlo v raném novověku, Ústí nad Orlicí 2011; Joachim BAHLcke - Thomas WinkelBaUER (Hgg.), Schulstiftungen und Studienfinanzierung. Bildungsmäzenatentum in den böhmischen, österreichischen und ungarischen Ländern, 1500-1800, München - Wien 2011 (zde studie několika českých autorů, K. Bobkové-Valentové, H. Kuchařové a M. Holého); Martin HolÝ, Schulbücher und Lektüren in der Unterrichtspraxis an böhmischen und mährischen Lateinschulen des 16. und frühen 17. Jahrhunderts, Zeitschrift für Erziehungswissenschaft 2012, 15, s. 105-119; Mlada HolÁ - Martin HolÝ, Středověké studijni nadace v Čechách, Mediaevalia Historica Bohemica 19/1, 2016, s. 87-109.

10 Václav BARTƯŠEK, Elementárni školství cirkevnich řádio v českých zemích v době baroka, in: Barokní Praha barokní Čechie 1620-1740. Sborník příspěvků z vědecké konference o fenoménu baroka v Čechách, Praha, Anežský klášter a Clam-Gallasův palác, 24.-27. záŕí 2001, Praha 2004 s. 601-608; Ludmila SochorovÁ, Školský řád sv. Voršily v Čechách v době baroka a osvícenských reforem Marie Terezie, Paginae historiae 11, 2003, s. 69-89; Rahel ČERNÁ-WILli, Základni vzdělávání v multilingválních kontextech 18. století: Připad Těšinska, in: Slavistika dnes - vlivy a kontexty. Konference mladých slavistů, II, říjen 2006, Červený Kostelec 2008 s. 103-120; Michal KNEBLiK, Škola - mezi disciplinou těla a ducha: triviální školy v Čechách 1774-1800, in: Dějiny těla: prameny, koncepty, historiografie, Červený Kostelec 2013, s. 131-148; Dana KAsPERovÁ, Metoda-obsah vzděláváni učitelů elementárnich škol a nástroj školské osvícenské reformy, in: Učitel ve střední a jihovýchodní Evropě: profesionalizace učitelského vzdělávání: historické a systematické aspekty, Praha 2015, s. 86-100; Tomáš KaSPER, Profesionalizace učitelského vzdělávání v českých zemích v pozdním osvícenství, tamtéž, s. 76-85; K. BobKovÁ-VAlentovÁ - M. Holý - M. Ondo GrečEnKovÁ, Církve, vzdělávání a věda, s. 211n., 219, 228n., 232, 236nn.; Michal KNeBLík, Učitelé nižšich škol v době reforem a osvícenství, Cornova. Revue České společnosti pro výzkum 18. století a Filozofické fakulty Univerzity Karlovy v Praze 6/2, 2016, s. 84-103. 
a mnohdy rozvíjené v budoucnosti, důsledky v oblasti mecenátu, budování individuálních či rodových knihoven stejně jako i vlastní literární činnost. ${ }^{11}$

Část studií i konferenčních př́íspěvků se pak soustředila také na městské obyvatelstvo, zejména opět na jeho elitní vrstvy. Především se to týká publikací Archivu hlavního města Prahy. ${ }^{12}$ Kromě uvedeného stály v centru pozornosti některých publikovaných prací také další specifické skupiny obyvatelstva, jako byly např́klad minoritní konfesní skupiny (např́íklad novokřtěnci či Židé). Za podstatné lze pak považovat práce vztahující se k mladoboleslavskému nálezu archivu seniora Jednoty bratrské Matouše Konečného, pro vzdělávání zejména monografii a edici Markéty Růčkové. Samostatnou, ovšem podstatnou kapitolu představuje pak edukace dívek. K této oblasti se vztahuje několik vydaných monografií i řada studií. ${ }^{13}$

Některé cenné podněty k dějinám vzdělanosti českých zemí vyšly pak v rámci činnosti Národního pedagogického muzea J. A. Komenského, případně také Muzea J. A. K. v Uherském Brodě. Až na některé výjimky se většinou jednalo o sborníky z konferencí, které sice předmoderní dobu nezř́́dka přesahovaly, ale přeci jen části z nich se k nim rovněž vztahují stejně jako i některé katalogy výstav. Tematicky podnětné byly např́klad práce $\mathrm{k}$ historii výuky dějepisu, profesionalizaci učitelského vzdělávání či vysvědčením jako specifické součásti dějin školství. U uherskobrodského muzea jde pak vedle jiných publikací zejména o studie publikované v časopise Studia Comeniana et Historica. ${ }^{14}$

11 Petr Vorel, Ditě na aristokratickém dvoře na počátku raného novovéku podle predstav Viléma z Pernštejna (,, Naučení rodičům “ a jeho obsahová interpretace), in: Tomáš Jiránek - Jiří Kubeš (edd.), Dítě a dětství napříč staletími. 2. Pardubické bienále 4.-5. dubna 2002, Pardubice 2003, s. 13-48; Alena NastoupilovÁ, Péče o déti předškolního věku a jejich výchova v dile Jana Amose Komenského, Unie Comenius. Bulletin č. 21-22, 2005, S. 3-11; Lenka VeselÁ, Knihy na dvoře Rožmberků, Praha 2005; Martin STEINER (ed.), Informatorium školy mateřské, Praha 2007; Martin Holý, Šlechtičtí vzdělanci z českých zemí a evropská res publica litteraria v posledni třetině 16. a v prvních desetiletích 17. století, Historie - Otázky - Problémy 1/1, 2009, s. 13-34; TÝŽ, Zrození renesančního kavalíra: výchova a vzdělávání šlechty z českých zemí na prahu novověku (1500-1620), Praha 2010; Jiří KuBEš, Náročné dospívání urozených: kavalirské cesty české a rakouské šlechty (1620-1750), Pelhřimov 2013; Zdeněk HoJdA - Eva CHODĚJovská a kol., Heřman Jakub Černín na cestě za Alpy a Pyreneje, I-II, Praha 2014; Lenka VeselÁ, Rytír a intelektuál: Hieronym Beck z Leopoldsdorfu (1525-1596) a jeho knihovna, Praha 2016.

12 Předmoderní vzdělanosti se dotýkají některé příspěvky z následujících sborníků vzešlých z konferencí a výstav Archivu hl. m. Prahy: Pražské městské elity středověku a raného novověku. Jejich promény, zázemi a kulturni profil, Praha 2004 (= Documenta Pragensia, dále DP, 22); Město a intelektuálové od středověku do roku 1848, Praha 2008 (= DP 27); Pražský student. Univerzitní studenti v dějinách Prahy, Jana RataJovÁ (ed.), Praha 2008; Ztracená blizkost. Praha - Norimberk v proménách staletí, Praha 2010 (= DP 29); Déti ve velkoměstech od středověku až na práh industriální doby, Praha 2012 (= DP 31); Město v prevratech konfesionalizace v 15. až 18. století, Praha 2013 (= DP 33).

13 L. Sochorová, Školský řád sv. Voršily; K. Bobková-Valentová - M. Holý - M. Ondo GreČenková, Církve, vzdělávání a věda, s. 223; M. RưČKOvÁ - J. A. ČEPELÁK (ed.), Studium a korespondence kněžského dorostu Jednoty bratrské; Marie MACKOvÁ, Voršilky v Čechách do roku 1918, Pardubice 2007; Milena LenderovÁ a kol., Žena v českých zemích od středověku do 20. století, Praha 2008, s. 83-92; M. HoLÝ, Vzdělanostní mecenát, s. 114, 129n., 163nn.; Magdalena PoKorná, Dívči vzdělávání, in: Jaroslav Pánek (ed.), Akademická encyklopedie českých dějin, IV, D-G, Praha 2015, s. 185-188 (zde i další literatura).

14 Magdalena Šustová (ed.), Stalo se v zemi české... Jak se vyučoval dějepis, Praha 2009; tÁž (ed.), Dějiny ve škole. Škola v dějinách (= Historia scholastica, sv. I), Praha 2010; Jana BARTošová a kol., Vysvědčení jako součást dějin školství: od 18. století po současnost, Praha 2011; Tomáš KASPER - Markéta PÁnKovÁ a kol., Učitel ve středni a jihovýchodní Evropè. Profesionalizace učitelského vzdèláváni: historické a systematické aspekty, Praha 2015; Jan ŠIMEK, Historie školních budov: od tereziánských reforem po současnost, Praha 2016. Bibliografie časopisu Studia Comeniana et Historica je dostupná na: http://www.mjakub.cz/bibliografie -casopisu-studia-comeniana-et-historica?idm=233 (ověřeno 4. 2. 2019). 
S dějinami vzdělanosti úzce souvisejí také dějiny pedagogiky. Větší syntetické práce, jež by se primárně zaměřily na období středověku a raného novověku, nevznikly. Přesto některé rozsáhlejší texty vztahující se k tomuto období částečně přeci jen byly vydány (Dějiny pedagogiky Tomáše Kaspera a Dany Kasperové z roku 2008). Ostatní přehledy dějin pedagogiky, jež byly ve sledované době publikovány, jsou zpravidla velmi nerozsáhlé a často nevalné, nezř́́dka až čistě kompilativní úrovně. Naopak řada cenných př́íspěvků k dějinám pedagogického myšlení do 18 . století včetně vyšla časopisecky, případně v různých výstupech z konferencí. Cenné jsou pak rovněž některé pramenné edice či chrestomatie textů k dějinám pedagogiky, např. objemná Chrestomatie z dějin pedagogiky vydaná v Karolinu $\mathrm{v}$ roce $2009 .{ }^{15}$

Za pozitivní lze pak rovněž považovat, že ve zkoumaném období vyšla také řada prací, knižních i v podobě studií, které se vztahují k jednotlivým vzdělancům, jejich intelektuálnímu backgroundu, učeneckým kontaktům u nás i v Evropě, literární činnosti apod. Za všechny budiž uvedena např́íklad monografie Aleny a Petra Hadravových, Tomáše Nejeschleby, Lucie Storchové, Vladimíra Urbánka, Jindřicha Marka či práce kolektivu vedeného Martinem Svatošem. Zde se dějiny vzdělanosti úzce propojují s intelektuálními dějinami, historií komunikace, dějinami filosofie, literatury či vědy. ${ }^{16}$

Pokud jde o všechny uvedené okruhy a jednotlivá témata, lze obecně říci, že z hlediska užitých metod nedošlo v posledních dvou decenniích v českém výzkumu dějin vzdělanosti k nějakému výraznému kvalitativnímu posunu. Na druhou stranu specifické vlastní metody př́liš nemají dějiny vzdělanosti ani $\mathrm{v}$ jiných zemích. Všude se $\mathrm{v}$ nich projevují zejména obecné badatelské trendy v sociálních a humanitních vědách, zejména pak v historiografii (dějiny každodennosti, biografistika spojená se sociostatistickými výzkumy, digital humanities založené na stále sofististikovanějších databázích apod.). Na rozdíl od zahraničí se u nás bohužel $\mathrm{v}$ dějinách vzdělanosti stále př́iliš neprosadily výrazně komparativní př́stupy. ${ }^{17}$

15 Zdeněk KuČERA - Vladimír ČTVERÁk a kol. (edd.), Chrestomatie z dějin pedagogiky, Praha 1999; Tomáš KasPer - Dana KasPerová, Déjiny pedagogiky, Praha 2008; Miroslav Somr, Kapitoly z déjin filozoficko pedagogického myšlení, 2. vyd. České Budějovice 2009; Tereza VAcínovÁ, Dějiny vzdělávání od antiky po Komenského, Praha 2009. Na řadu nerozsáhlých prací - úvodů do dějin pedagogiky zde nelze odkazovat.

16 Tomáš NejeschleBA, Jan Jessenius v kontextu renesanční filosofie, Praha 2008; Vladimír UrBÁNEK, Eschatologie, védéní a politika: přispěvek $k$ dějinám myšlení pobélohorského exilu, České Budějovice 2008; Lucie Storchová, Paupertate styloque connecti. Utváreni humanistické učenecké komunity v českých zemích, Praha 2011; TÁž, Bohemia and Moravia, II, Bohemian school humanism and its editorial practices (ca. 1550-1610), Turnhout 2014; Jan MartíneK, Martiniana. Studie o latinském humanismu včeských zemích, Praha 2014; Jindřich MAREK, Václav Koranda mladší. Utrakvistický administrátor a literát, Praha 2017; Josef FöRSTER - Ondřej PodavKA - Martin Svatoš a kol., Historia litteraria: v českých zemích od 17. do počátku 19. století, Praha 2015; Martin Svatoš a kol. (edd.), Johann Peter Cerroni. Scriptores Regni Bohemiae I, III, Praha 2016-2017. Na početné práce manželů Hadravových nelze jednotlivě odkazovat. Jsou evidovány v databázi biblio.hiu.cas.cz.

17 K využití databázových systémů v oblasti dějin vzdělanosti vznikly v ČR některé cenné studie. Ty se částečně dotýkají také prosopografie. Srov. alespoň Jana BorovičKovÁ, Počítačové zpracováni univerzitnich matrik-program Paradox a prosopografie pražské právnické univerzity, Mediaevalia Historica Bohemica 7, 2000, s. 201-231; TÁž, Elektronické informační zdroje pro dějiny univerzit a vzdělanosti v evropských historických datových archivech, AUC-HUCP 47/1-2, 2007, s. 269-274; Jiří STočEs - Jana BorovičKovÁ, Nové metody - prosopografie, in: Ludmila Sulitková - Hana Barvíková - David Pazdera (edd.), Studie a články k dějinám vědy a vědeckých institucí, Praha 2002, s. 47-61. Viz také Kateřina BoBkovÁ-VALENTovÁ - Hedvika KuchaŘovÁ, Problémy standardizace historických biografických pramenů při jejich databázovém zpracování, in: X. sjezd českých historiků. Ostrava 14.-16. 9. 2011, sv. 5, Ostrava 2017, s. 73-82. 
Uvedené snad souvisí rovněž s institucionální základnou výzkumu. Kromě specifických komeniologických pracovišst včetně uvedených muzeí i oddělení pro komeniologii a intelektuální dějiny raného novověku Filosofického ústavu AV ČR zůstává stále jedinou badatelskou institucí založenou především pro výzkum dějin vzdělanosti Ústav dějin Univerzity Karlovy a Archiv Univerzity Karlovy. Při jeho relativně nepočetném obsazení a klíčových archivních úkolech přitom není možné pokrýt výzkum dějin vzdělanosti komplexně. ${ }^{18}$

Jednotliví badatelé profilovaní $\mathrm{v}$ této oblasti jsou pak zaměstnáni rovněž na některých vysokých školách, ústavech AV ČR stejně jako v dalších institucích. Bohužel podobně, jako to konstatoval před 18 lety Michal Svatoš na Sjezdu historikủ v Hradci, ${ }^{19}$ i dnes stále ještě chybí koordinační centrum výzkumu dějin vzdělanosti, jež by nejen iniciovalo bádání o některých zásadních a dosud nezpracovaných tématech, ale také bylo platformou pro výměnu informací, prípravu společných grantových projektů, konferencí apod. Za klíčový úkol takového grémia bychom pak považovali rovněž důraz na výraznou transdisciplinaritu výzkumu a koordinaci zpř́ístupňování pramenů. ${ }^{20}$

Pokud jde o ona bílá místa českých dějin vzdělanosti, těch lze identifikovat celou sérii. Nejde přitom pouze o dílčí témata spjatá s dějinami pedagogiky, jednotlivých vzdělávacích institucí, jejich učitelského obsazení, žákovské struktury apod., ale především pak o jejich důslednou komparaci s vývojem mimo české země. Výrazně pak chybí zejména syntetické práce, které by se v první řadě pokusily v moderní podobě postihnout dějiny vzdělanosti ve stále nedostatečně probádané pobělohorské době, ve druhé řadě pak zachytit klíčové vývojové trendy např́ič celou předmoderní dobou. Jedině ohled na longue durée, stejně jako pohled komparativní umožní nově pochopit celou řadu dílčích jevi̊ a procesů, které se v námi zkoumané oblasti mezi středověkem a 18. stoletím odehrávaly.

MLADA HOLÁ - MARTIN HOLÝ

\section{Geschichte der mittelalterlichen und frühneuzeitlichen Bildung in der tschechischen Geschichtsforschung. Tradition - aktuelle Trends - Perspektiven}

\section{ZUSAMMENFASSUNG}

Der Beitrag knüpft an das Fazit an, welches Michal Svatoš in seinem Referat auf dem 8. tschechischen Historikertag in Hradec Králové 1999 gezogen hatte und das 2002 publiziert wurde. In dem Beitrag wird versucht, die Entwicklung der tschechischen Geschichtsforschung über die Geschichte der Bildung in der vormodernen Zeit, insbesondere für den Zeitraum des 14. bis 18. Jahrhunderts systematisch nachzuzeichnen. In einem breiteren europäischen Kontext konzentriert er sich nicht nur auf die einheimische Tradition der Forschung, sondern vor allem auf ihre aktuellen Trends, die sich aus den untersuchten Themen und neuen Methoden der ausländischen Historiographie bzw. der verwandten Sozial- und Geisteswissenschaften ergeben (Anthropologie, Philosophie, Pädagogik

18 Základní informace o výše již zmíněných pracovištích jsou dostupné na https://udauk.cuni.cz/ a http://komeniologie.flu.cas.cz/cz (oboje ověřeno 4. 2. 2019). V prvním případě umožňují vhled do aktuální činnosti pracoviště také výroční zprávy.

19 M. Svatoš, Místo , dějin vzdělanosti“ v poválečné české historiografii, s. 21.

20 Uvedené úkoly by mělo plnit nově vzniklé Centrum pro dějiny vzdělanosti, které bylo při Historickém ústavu AV ČR založeno ve spolupráci s Ústavem dějin a archivem UK k 1. 9. 2018, tedy již po termínu odevzdání této studie. 
bzw. Erziehungswissenschaft, Soziologie u.a.). Hinsichtlich einer Analyse der Forschungstrends auf dem Gebiet der Geschichte der vormodernen Bildung konzentriert sich der Beitrag vor allem auf den wissenschaftlichen Ertrag der letzten fünfzehn bis zwanzig Jahre. In ihrem abschließenden Teil versucht die Studie, mögliche Themen der weiteren Forschung zu formulieren, und zeigt die Möglichkeiten ihrer methodologischen Handhabung auf.

Deutsche Übersetzung Wolf B. Oerter

Mlada Holá

Katedra PVH a archivního studia FF UK, Praha

mlastep@seznam.cz

Martin Holý

Historický ústav AV ČR, v.vi., Praha

mholy9@gmail.com 